\title{
The Poetry and Prose, as Well as the Impact of Communist Ideology in the Albanian Literature of the ' 80
}

\author{
Dhurata Lamçja
}

\section{Abstract}

Albanian literature has come a long way through the many historical events it has passed and managed to survive. One of the harshest periods for Albanian literature, has not come as a consequence of external invasion, but from within. The communist dictatorship in Albania, which started in the remains of the Second World War, and lasted up until 1991, besides controlling the politics, foreign relationships, economy and social structures, used art and in particular literature as a weapon to demolish free thought and enforce its ideology through the canonized structures and cliches, such as the martyrdom. This led the Albanian authors to find new ways hidden inside literary figures, which they mastered, to spread their message and express their true thoughts and feelings beyond the censorship, and trained the readers to read through and understand the intentions of the authors.

Keywords: literature, poetics, prose, ideology, socialist-realism

\section{Introduction}

The traditional normative meaning of the word "poetics", as defined by the first author to use the term, Aristotle, was related to the totality of aesthetic rules or perceptions related to poetry. Paul Valéry, head of the Department of Poetics at the Collège de France linked this term to everything related to the creation or composition of the work, for which discourse is both a subject and a tool (Valery, 1957). Genre, discourse, dialogue, etc., are concepts that contain different poetics. The theory of artistic creation of discourse lies at their core. Consequently, the literary work is created on the basis of a combination of analyzable procedures and the composition of comprehensible forms. The concept of Poetics also includes literary theories.

Considering the above meanings, the concept of "poetics" includes the totality of the writer's conscious choices in terms of composition, style, gender or themes (Todorov, 1979). Therefore, poetics is the determinant of a series of literary forms, where different works are positioned. Persida Asllani mentions several types of poetics, such as: immanent poetics, poetics of literary movements and authorial poetics (Asllani, 2021). Immanent poetics are organically related to the work in which they are born 
and functionalized. It enables the evaluation and characterization of the creativity of the work of authors such as De Rada, Migjen, Kadare, etc., through the historicity of their works.

According to Mihail Bakhtin, "poetics", systematically defined, should be the "aesthetics of literary art"(Bakhtin, 1978, p. 26). In this sense, Poetics is not merely a reflection on discourse, but encompasses a general aesthetic that extends to all forms of artistic expression. The immanent historicity of the work of art or the historical reporting of a fact or discourse in its "objective" situation in history is created only when the art world is "divided into separate, autonomous and individual entities." (Bakhtin, 1978, ibid). Even in the case when historicity leads to subjectivism, poetics reveals another historical subjectivity of receptivity, namely the inscription in the text of the literary work (Bakhtin, 1978).

\section{Methodology}

This paper is based on the qualitative approach. The literature review on the chosen topic is a methodology used in order to collect data from studies as well as the works of Albanian and foreign authors to better understand the elements of poetics in the short prose of the 80's, but not only. Literature review is an essential feature of academic research, because fundamentally, knowledge advancement must be built on prior existing work, this way we can also evaluate the validity and quality of existing work against a criterion to reveal weaknesses, inconsistencies, and contradictions (Paré et al. 2015). The literature not only analyses the perceptions and academic publications of other authors who have researched the same issue, but also dwells extensively on the works and authors of the communist years in Albania. This, to reflect on the deep impact of communism on the subconscious of the authors widely reflected in the literature of the 80s in Albania.

\section{Literature Review}

The creative essays of Konica, Koliqi, Kadare, and other Albanian authors are much more than a reading contract where the genres, types or styles of writing are clearly distinguished. They enable in-depth comparisons with worldviews and life experiences. If we explore the poetics of the literary genre, we will notice that it encompasses an evolving horizon. The dialogue between the work and the public constantly redefines this horizon, which transcends the text itself and the world. Norms of social communication are produced, confirmed, or substantially opposed by literary genres (Jaus, 1978). The Albanian letters of Koliqi and Migjen are traces of efforts and trials in this direction.

For the author Anton Pashku, violating the norm of communication means showing the society the dangerous lack of "communication" in which it is located. Thus, the "normative" violation is committed in function of a new and authentic norm of communication, which often takes the form of absurd writing. Taking into account 
the problems of genre evolution within the History of Literature, in recent studies, the need to examine another aspect of the nature of the artistic text emerges.

Finally, Antoine Compagnon states that: "Genres are obligations and conventions in terms of norms and rules, less coercive than productive" (Compagnon, 1998, p. 99). From this point of view, the choice of genre type by De Rada, for the design and writing of Songs of Milosao (alb. Këngët e Milosaos) can be interpreted as a normative solution for the development of a specific "discourse game", which finds recognition, identification and ultimately use of some literary rules common between him and the Arbëresh community, between him and the Arbëresh context of the work itself (Asllani, 2009). In order to have communication between them, it had to be played in the plane of a literary "familiarity", which dictated in a way not only the linguistic norm but also many of the formal choices of the work. This practice in Arbëresh literature is encountered to some extent in the young Gavril Dara and is recaptured with great interest by Zef Skiroi.

The compilation and writing of the epic work "Lahuta e Malcisë" by Gjergj Fishta is encouraging for a similar reasoning. It is clear how the author of Lahuta is in search of the literary "familiarity" of the work, so much so that he reached the anecdotal episodes of its popular "borrowings". Whereas in Kuteli, the authorial definition of the narrative for his fictions in prose serves both as a normative structural element of their writing and reading. The familiar face of the narrative type of the tales ensures the conveyance of both the énoncé and its formal features. Therefore, it can be said that for these authors the genre norm is an instance that ensures the comprehensibility of the text from the point of view of composition and context (Asllani, 2009).

To this reasoning we could add another issue of literary poetics, such as the dialogical aspect of novel discourse. Against the conception of the novel work as a self-contained author's monologue, without the possible intervention of another denunciation, the novel emerges as an internalized dialogue of his voices and multiple discourses, or, in Bakhtin's terms, as dialogued in all its linguistic strata. The search to classify the discourse types inscribed in the Albanian novel and to compare these types from the point of view of the poetics of the novel would undoubtedly bring a new dimension to the history of this genre.

This kind of research would allow us to define more clearly not only the appearance of the first modern novel in Albanian literature, but also to re-treat the possibilities of its appearance, although embryonic, in the form of projects, in Konica, Koliqi and especially Migjeni. Here are a few examples to point out the operational value of immanent Poetics and the possible construction of the historicity of literary works or phenomena within the History of Literature. But this thesis would be incomplete without considering two other aspects, such as the Poetics of Literary Movements and Authorial Poetics. The basic character of a literary movement is determined by the fact that a group of writers becomes aware of the changes in how art works, the 
changes in the perspective that writers have on the universe in which they project their work, and the chord on what they can expect by those who will receive these works. Every literary movement is a revision not only aesthetic, but also ontological to what precedes it. It modifies the structures of poetic analogy, the social archetype of the poet or artist. All other problems of rhetoric, verse, glossary, thematics, are secondary details if we compare them with this collective consciousness of the role of the artist in front of the world considered both in subjective terms and in objective terms (Asllani, 2009). But this aspect becomes more complicated in the conditions of a literature where literary movements cannot be clearly crystallized as movements of a group.

On the contrary, today we can say that this "absence" speaks much more than a possible presence in the Albanian literary and cultural world, instead of a genuine literary movement we have the will of a writer who, aware of the great ontological change it is offering, turns into the coryphaeus of something that will one day come, that will crystallize only and through the literary text. It becomes more than clear that the publication of Albania and Konica's "Kohëtore e Letrave shqipe"1 becomes the "official" milestone of modernity in Albanian letters, without even waiting for the publication of poetic prose or stories and essays from Konica. The scholar and historian of albanian literature Sabri Hamiti rightly sets here the milestone for the beginning of the period of Modern Albanian Literature. But in the absence of a group poetics, the period 1990-1945 offers us one of the riches that is still underused in the compilation of the History of Literature: authorial poetics (Asllani, 2009). Under this name three active groupings can be proposed within this literary period (Asllani, 2009, p. 141):

\section{Analysis}

The process of formation of socialist realism in literary creativity goes hand in hand with the crystallization of "down" social consciousness, within the psychology of the masses and "up", with the strengthening of the ideological political institutes of the state. Endless discourses between circles of artists happened in this plan, so competent is the new artistic unity as the "soc-realist method" that gained the status of state doctrine (Misiri, 2015).

During this period, literary production was forced to conform to the rules of the official method of socialist realism, which led, for the most part, to a literature deeply rooted in ideology, without true values (Gjika, n/a). Socialist realism in Albanian literature, in essence, took the form of a dynamic canonism (Even-Zohar, 1990). This was a method that was not imposed through texts, but prevailed as an external model of literary rules and norms, which served as the basis for literary productions.

\footnotetext{
1 "Kohëtore e letrave shqipe" or "Timeline of albanian literature" was published by Konica in the Albania magazine, on the basis of theoretical-modern premises. In this work, Konica follows the Albanian literary creativity and examines some of its most prominent phenomena.
} 
Socialist realism was a creative method of literature and the arts, applied first in the former Soviet Union and then more intensively throughout the former communist countries during the twentieth century. In 1936, the Soviet government took measures to implement the undisputed total socio-realist method of all the arts in the USSR (Even-Zohar, 1990).

The notion of aesthetic "realism" had to do with the definition of "socialist", brought the practice of subjugating literature and the arts to ideology. The demands for the use of the techniques of socialist realism actually became an obstacle, an anxiety to stop the creativity that for years was avoided against the spiritual life of the people, so that the writers created in their majority mediocre works of conformists who blew trumpets, which served propagandistic tendencies. This method was based on Marxist-Leninist ideology and philosophy. It was a method of political engagement of writers and artists in accordance with the ruling ideology, the communist ideology and through it, the communist state exercised its total control over the creative processes in literature, arts and culture.

In the late 1980s, realism became a literary and historical term, but in the embryonic stage of many characteristics, soc-realism literature is defined as "heroic realism", "monumental", "social", and "one-sided". Socialist realism promoted schematism, political adaptation, solidarity with the ruling ideology and propaganda of the time. The literature and arts of socialist realism followed the political line and ideological principles, charging themselves with agitating roles (Even-Zohar, 1990, p. 61).

The first tendencies for a politically and ideologically engaged literature in accordance to the demands of socialist realization in Albania arose during the AntiFascist National Liberation War. A group of writers and artists who took an active part in the war and played a role in its press (F. Gjata, Sh. Musaraj, Ll. Siliqi, K. Jakova, etc.) embarked on the creative path as founders of socialist realism in Albania.

Undoubtedly the factors of the prohibition of literature and its obstruction by the socialist method dictated by the politics of the time in the years 1949-1952 constituted paradoxical circumstances; when the terror started from the League of Albanian Writers with Malëshova, then Trebeshina and so on. At the time when this method ruled in most of the literature, in Albania, various authors faced it, in their behavior.

Art was suppressed, used in the worst way and was a function of political propaganda, as some artists were presented violently as a cliché of socialist realism, where the best sense of civilization like the love and intimate world of humanity was violated. As freedom is struck, precisely when the thread of artistic creation becomes impossible to enter and cross the fence of socialist realism, it must be turned either into a megaphone to spread utopia and meaningless themes which were to have a significant impact on the consciousness of the masses, or to camouflage in classical 
symbols of myths to survive true literature in the sense of what the writer wants, as Kadare did.

The vast majority of Albanian literature, written and published within the state borders of Albania, was faithful to the principles of socialist realism, which brought a propaganda literature, without true aesthetic and placard values. One of the peculiarities of the delivery of socialist realism in Albanian literature was that it continued to be tightly bound to ideological dogmas and canons until the end, unlike other former communist countries.

Various authors weaved the thread of prose in Albania such as Dritëro Agolli, Dhimitër Xhuvani, Ali Abdihoxha, Skënder Drini, Sabri Godo, Vath Koreshi etc., while at the head of the poetic lyrics were Fatos Arapi, Ismail Kadare and Dritëro Agolli, as a young generation of talented poets. Sometimes writers were heroes, somewhat justified for what they did, because the dictatorship did not leave many choices, but the worst was the silence or rejection of the artistic creation of Albanian writers, because the writer is like a prophet who endures the pain of saying the words of truth , as the Promethean myth is transmitted to all generations since antiquity.

This false philosophy of life, also represented in the surviving literature by easing socialist censorship, always created models in the cause-and-effect relations of structure (Even-Zohar, 1990, p. 97), in function of the dynamic structure of movements within it as expression of a polemical religion, a religion of becoming a martyr, an extremism in sacrifice, because even though all Albanians became atheists, they had to believe in the labor party, and die for the masses at work. All life experiences, the reflection of social consciousness, where they felt the positive values of the heroes, artistically expressed, gave the configuration in the understanding of life. The critical, theoretical and aesthetic thought of that time, limited the line of Albanian novels based on the principle of ideas, characters, conflicts, formation of composition, narrative flow, stylistic and linguistic characteristics in detail, comprehensive to soc-realist methods.

However, criticism of the time of socialist realism in Albania was not absent, it served as a censor based on a semi-pragmatic platform of socialist realism and the articles in the newspapers of the time, the most discussed novels about the development of a large industry are reflected in the behavior of the working class and the positive hero, the bravest should not be afraid of death. In all the novels the heroic force appeared in superlative form, to sacrifice his life for others, it has to do with building the industry of the Albanian country.

The literature of socialist realism has presented the Albanian society better than it was in reality, given the work in the form of novels and stories of Dhimiterr Xhuvani and some of the stories of Anastas Kondo (Even-Zohar, 1990, p. 97). There were also epic monumental works that dealt specifically with the various historical events that happened in the time period between the two world wars, a choice to escape from the 
present reality, like Jakov Xoxa. The author is always there with his presence, the subject and the object of his fiction, showing his subjective feelings and views, always aiming to draw the first plan himself. His personality in war with his ego goes beyond the desire to create something else, perhaps an image we have never encountered before. Mystification begins here. The author says it is deed, and believing or not constructing his myth makes his deed immortal after torturing the idea of whether it is worth it or not. It is in human nature to seek immortality (Even-Zohar, 1990, p. 98). Life and death, being mortal and eternity are the existential dichotomies of the author. Thus, the reference to Albanian authors in most of their work has done to serve something utilitarian, be it an idea such as homeland, language, collective essence, ideology, doctrine, ethnicity, etc.

The Albanian author learned to be a social activist, a fighter, prisoner, liberator, censor or censored, persecutor and persecuted, anti-fascist, anti-communist, cynical, aggressive, peaceful, indifferent, dissatisfied. Emphasizing the fact that being an atheist means that either you are a god or you are an abandoned orator. It may have been misunderstood, misinterpreted indefinitely, but the author was a conductor of a religion evoking the surprise that a wonderful life has never happened before in capitalist society and if not, he would be anathematized.

As we know, after '90 years through talented writers, all over Europe, Albanian literature began to penetrate into the souls and sensibilities of Albanian creative literature, as Konica, Koliqi, Kuteli, etc., recorded some of the highest peaks of Albanian literature, types and genres, such as epics, literary criticism, etc. Created for both Albanians and foreign readers, writers continue to give us a complete encyclopedia of Albania and its people.

\section{Discussion}

A mosaic of history and culture, language and literature, spirituality and psychology of the Albanians of the world, with extensive information and in-depth knowledge, harmonizing scientific objectivity with an entertaining account of the author highlights the individuality and nature of the Albanian people, but also in the Balkan and European context. It is assumed that the creative inspiration did not stop immediately by establishing communist rule, outside Albania, Kuteli continued to be a natural continuation of the war against censorship publishing literature that was nonconformist with the ideology of the time nevertheless (Even-Zohar, 1990).

The novel in Albanian literature flourished between the 60s and 90s of the twentieth century, and explained the social, cultural and educational processes, in the speckles of the political ideology of the time, but at the same time left the space empty for the reader to go inside the subconscious world of a writer who truly understands what a reader needs. Being a writer in Albania during the ' 50 s and' 90 s involved a lot of pain, self-sacrifice and a truly prophetic prediction, they did not do any compromise in their act of creation; their freedom and creative spirit was already summed up in 
hidden parts of their unconsciousness, as dreams that exist and communicate with us silently within the walls, where the only noise that was heard is the noise of their pen. For such writers freedom came to punish the fabrications of the regime.

The young "Albanologists" today are trying to bring social, ideological arguments to attack the Albanian language and its antiquity, Skanderbeg and its history in the name of demeaning efforts (Even-Zohar, 1990). But today, Europe and the fascination with harmony fits the majority of Albanians, convinced that the motherland appears in beliefs and it is found in accordance with the best literary thought. This deep awareness of national history gave this sound the prophetic voice of a spokesman defending his tribe in the depths of the most visible and hidden riches. Identity issues are a phenomenon related to the process of modernization of society itself and in this process the Albanian writer should be the first intellectual, feeling lucky for his identity and building his myth in the wake of the wonderful fabrications of this country, of its disagreement in literary terms match the fate of the nation in its essential historical moments.

\section{"Drawer" and forbidden literature}

In addition to the literature published in Albania, there was also the literature of prisons and persecuted authors, written by creators who, due to political persecution, were deprived of publication, but who continued to write and publish their books in prose, poetry, dramaturgy, memoirs, etc. Among the most representative authors we can mention Kasëm Trebeshina, Bilal Xhaferri, Bashkim Shehu, Fatos Lubonja, Zef Zorba, etc. It must be said that this literature due to the Stalinist regime in Albania was impossible to communicate with the reader, so its publication and reception by the public began after the '90s. However, in communist Albania, alternative literature never managed to be formed and appear as artistic dissidence, with creative principles imposed, and with a clear artistic opposition to socialist realism, with any elaborated treatise or aesthetic doctrine.

In addition to the "drawer" literature, it is worth mentioning the censored or banned works, which despite the coercive measures, did not remain completely faithful to the socialist realization, so they did not remain hostage to dogma and therefore were banned and censored. These and other works were banned or removed from circulation for blackening reality, formalism, extravagance, foreign influences, decadence and ideological omissions. There were writers and poets who were temporarily deprived of their right to creativity or who were sentenced to imprisonment or exile for ideological reasons related to their creativity or life (S. Malëshova, K. Trebeshina, Dh. Xhuvani, V. Zhiti etc.). 


\section{The main metaphors of totalitarian discourse}

Some of the main metaphors of totalitarian discourse listed by the scholar Vehbiu (2007) are easily verifiable in the literature produced in this period:

a. The siege metaphor according to which the Albanian people for centuries had to face a fight for life or death with the external and internal enemy, always winning. One of the most illustrative examples of this metaphor is the novel "The Castle" by Ismail Kadare.

b. The image of the enemy, this metaphor occupies a central place in totalitarian ideology and mythology, which is strongly transmitted and cultivated in literature as well. It can be said that almost exclusively in all Albanian social realist literature the figure of the enemy was accompanied by a negative emotional charge; he was always savage, ruthless, bloodthirsty, cruel, bloodthirsty, etc. An exceptional case is this figure in some works of Petro Marcos, where he appears in more humanized forms ("The Last City", "The Night of Ustica").

c. The positive hero was always the antipode of the enemy, the representative of the healthy socialist society and thus of the invincible Albania. It had an ideological, didactic and literary function (Kuçuku, 2007). This literature in full coherence with the party line was functionalized in creating the cult of the young man whose blood boiled in the veins, who worked day and night for the construction of socialism.

d. Building the cult of the leader, respectively Enver Hoxha, was a permanent task of Albanian literature. Many texts are dedicated to the figure of Hoxha as a far-sighted and eternal leader.

e. The sick and decadent figure of the micro-bourgeois intellectual (Gjika, N / A) is often present in the literary works of the communist period.

\section{The value of looking at the diachronic and synchronic dimension for the Albanian poetry of the ' $80 \mathrm{~s}$}

In addition to prose, the creativity of 80s authors in poetry is worth analyzing as a multitude of interrelated profiles. Diachronic examination is inevitable in literary historiography. According to the researcher Dado (2011) this is about an initial approach to the study of the history and development of our literature. It is based on the interpretation of a work, or literary phenomenon as a historical category, not just seen in a chronological series of literary phenomena, but under the exact concept of diachronic analysis, which is understood as the determination of the factors that make poems perceived as new, to the extent of realizing the meaning and changing the creative principles with those of the previous authors.

The other dimension, the synchronic one, as a cross section that fixes a literary moment, would serve us to deepen in the stage of literary development, to better penetrate the literary structure of a certain moment, to give the hierarchy of values 
between works. Access to the two dimensions comes naturally intertwined. Genete thought there was no gap between the diachronic and the synchronic dimension.

As a result of this reasoning, it can be said that literature represents a whole system of works, which, being enriched with new works, remains a constantly changing whole. The period under consideration is a part of the mosaic of Albanian poetry. It comes as a result of a series of changes and developments in time, which follow each other and can be seen as a bridge-period, in relation to the previous poetry and poetic phenomena as innovations, which took a more complete form after the years' 80 .

\section{Conclusions}

Regardless of the value of the external point of view, the moment we evaluate, compare and divide individual factors in the works of poets, only the literary criterion can provide a satisfactory explanation in this regard. It would be a wrong approach to equate the meaning of the work only with historical and social reasons. The fact that the work will be based on the historiographical, chronological principle, does not mean that they will constitute the only point of view for the issues that we will address. We can evaluate many time details as factology, but that would be completely against the determination that literature is only the offspring of freedom, or the coercion brought by systems, which can be violent, or liberal, in terms of artistic creativity. The well-known writer I. Kadare asserts that historical facts, history, time with its peculiarities, cannot stop literature from its usual way of development.

In conclusion, we can state that socialist literature of realism functioned with many authors, but it is difficult, if not impossible, to find authors not impacted by the communist ideology, with or without their will, in this literature period. The political conditions of that time period in Albania made it impossible to publish and accept an alternative literature to socialist realism. Meanwhile, there are talented authors who in the poetics of literary discourse did not remain orthodox to the dogma of socialist realism, but this extends only to the immanent aspect of the text, as a narrative structure, while in the semantic plan the non-revision of Albanian communism made it impossible for a work to be published being not politically in coherence with the messages of power, ideology, which are also the essence of socialist realism. There are no systems that make a literature bad, or good. Literature, as spiritual creativity, knows how to and can always survive. It has been said many times; it is not only freedom that provides a culture, but there are several factors. In this way, we give due value to the historical perspective of the issue.

\section{References}

[1] Asllani, P. (2010). Poetics as palimsest and the history of Albanian literature. Scientific Conference:The history of Albanian Literature held in 30-31 october 2009, Prishtinë, 2010, pp. 136. Available at: http://www.ashak.org/repository/docs/HISTORIA_E_LETERSISE_SHQIPE_P ER_WEB_94044.pdf (accessed in 23.06.2021). 
[2] Bakhtin, M. (1978). "Esthétique et théorie du roman", Gallimard, pp. 27.

[3] Ciko-Kelmendi, M. (2009). "Kadare ndryshe", Published by "Naimi”, Tiranë, pp. 61-46-109.

[4] Compagnon, A. (1998). “Theorie de la literature: La Notion e Genre”, Available at https://www.fabula.org/compagnon/genre.php. (accessed in 23.06.2021).

[5] Dado, F. (2011). "Sfida teorike të historiografisë letrare-Historia e sistemit tonë letrar në dy plane: Diakronik e Sinkronik", Published by Bota shqiptare, pp. 248-266.

[6] Even-Zohar, I. (1990). Polysystem Studies; in "Poetics Today". International Journal for Theory and Analysis of Literature and Coomunication, Vol. 11, No. 1, 1990, pp. 19.

[7] Gjika, E. (N/A). 'Written in the head' - The indoctrinated literature of Socialist Realism and the unpublished literature under its dictation; In Consequences of dictatorship - Attitude towards oppression and lessons learned, KonradAdenauer-Stiftung V, Tiranë, pp. 59.

[8] Jaus, H. R. (1978). "Pour une esthétique de la reception”, Gallimard, Paris.

[9] Kuçuku, B., "Historiografi, risi, shformime, Letërsi shqipe bashkëkohore", Published by Toena, Tiranë, 2019, fq.28.

[10] Misiri, L. (2015). "Myth and Antimyth in the Fictions of Socialist Realism in Albania”, European Journal of Language and Literature Studies, Vol. 1, Ch. 2, 2015, pp. 96. Available at: https://journals.euser.org/files/articles/ejls_mayaug_15/Laureta.pdf (accessed in 23.06.2021).

[11] Pare, G., Trudel, M., Jaana, M., Kitsiou, S. (2015). Synthesizing information systems knowledge: A typology of literature reviews. Information \& Management, Vol. 52, Issue 2, pp. 183-199.

[12] Todorov, T. (1972). Poetique; in Dictionnaire encyclopédique des sciences du langage. Le Seuil, "Point Essais”, 1979.

[13] Valery, P. (1957). Propos sur la poésie; in uvres, Gallimard, "La Pléiade”, I, pp. 1362.

[14] Vehbiu, A. (2007). Shqipja totalitare. Published by “Çabej”, Tiranë, pp.184230. 